Jakub Dotlačil

University of Groningen $^{* *}$

\title{
EXPERIMENTAL EVIDENCE FOR NEG-RAISING IN SLAVIC ${ }^{* * *}$
}

\section{INTRODUCTION}

Neg-raising (NR) is an interpretational phenomenon: in biclausal structure like (1), negation of the root predicate (think) is most saliently interpreted on the embedded predicate, i.e., (1a) is normally interpreted as meaning (1b). Not every predicate demonstrates this property, however. For instance, verbs of communication are not negraisers, cf. the intuition that John says that it's not raining does not follow from John doesn't say that it's raining.

\section{(1) a) John doesn't think that it's raining. \\ b) $\sim$ John thinks that it's not raining.}

The NR interpretation is not predicted by the standard semantics of propositional attitudes (see, e.g., Hintikka 1969). For example, the verb think is formalised as a universal quantifier over possible worlds, restricted to some modal base - see (2). This predicts that (2a) does not entail (2b). Thus, it seems that the standard semantics correctly characterise communication verbs, but they fail for verbs like think. To put it differently: if we want to formalise the reasoning from (1a) to (1b), something more must be said about NR predicates.

(2) $\|$ think $\|(p)(a)(w)=\forall w^{\prime} \in M(w, a)\left[p\left(w^{\prime}\right)\right]$

a) $\neg\left[\forall w^{\prime} \in M(w, a)\left[p\left(w^{\prime}\right)\right]\right]$

b) $\nrightarrow\left[\forall \mathrm{w}^{\prime} \in \mathrm{M}(\mathrm{w}, \mathrm{a})\left[\neg \mathrm{p}\left(\mathrm{w}^{\prime}\right)\right]\right]$

While think is probably the most well-known example of NR predicates, other propositional attitude (PA) verbs are neg-raisers, too. Since Horn (1989), it has been

* docekal@phil.muni.cz

** j.dotlacil@gmail.com

*** We would like to thank the audiences at SinFonIJA 8 and FDSL 11, the organizers, editors and especially two anonymous reviewers of Linguistica for their useful comments and questions. We would further like to thank various people who commented on previous versions of this paper, especially Viola Schmitt, Jacek Witkoś and Joanna Błaszczak. Any flaws remain our responsibility. 
common to split NR predicates into five classes, and we will use this categorisation in the current article as well:
a) intention (want, intend, ...),
b) obligation (advise, should, ...),
c) perception (seem, appear, ...),
d) opinion (know, believe, ...),
e) probability (probable, likely, ...).

Most research studying NR focuses on English. ${ }^{1}$ One notable exception is Bošković \& Gajewski (2009) (henceforth: B\&G) and Dočekal (2014), which consider Slavic languages without articles. B\&G argue that NR is absent in these languages and demonstrate how the finding follows from Gajewski's (2005) NR theory, which is a modern, sophisticated, and updated version of Bartsch's (1973) presuppositional approach to NR. In contrast to B\&G, Dočekal (2014) argues that predicates of intention and obligation ( $\mathrm{a}$ and $\mathrm{b}$ above) pass standard tests for neg-raisers in Czech (a Slavic language lacking articles), that is, Czech has NR predicates, at least in Dočekal's introspection. There are three tests Dočekal (2014) considers.

As discussed already by Lakoff (1969) (see also Gajewski 2005, 2011 for a recent discussion), strict negative polarity items (NPIs) can be licensed by negated NR predicates. We will discuss properties of strict NPIs later in the paper. At this point, it suffices to say that until, modifying punctual events, is standardly considered an example of a strict NPI and that we see that until tomorrow is possible when embedded under negated NRs, (3a), and ungrammatical under non-NR predicates, see (3b).
(3) a) Bill didn't think that Mary would leave until tomorrow.
b) *Bill didn't say that Mary would leave until tomorrow.

The second standard test for NR-hood is the cyclicity of NR inferences. For example, (4a) is most saliently understood as (4b), in which the negation is interpreted on the most embedded predicate. This inference is broken if any of the predicates is a non-NR predicate.

(4) a) I don't believe that he wants me to think that he wrote it.

b) I believe that he wants me to think that he didn't write it.

The third standard test for NR-hood concerns the inference that NR predicates yield when appearing in the scope of a negated universal, e.g. (5a) implies (5b).

(5) a) Not every student thinks that John is a good teacher.

b) There are some students who think that John isn't a good teacher.

1 For recent theories of NR, see Gajewski (2007), Romoli (2013), and Collins and Postal (2014). 
According to Dočekal's intuitions, Czech NR predicates pass all three aforementioned tests. However, judgments related to NR are subtle and difficult. For this reason, we want to consider the existence of NR in Czech experimentally. We argue that the experiment confirms Dočekal's (2014) position and provides evidence against the empirical claim of Bošković \& Gajewski (2009). We interpret our data in the scalar framework of NR (originally coined by Horn 1989 and formalised currently in Romoli 2012, 2013).

\section{EXPERIMENT}

\subsection{Method}

\subsubsection{Introduction}

The experiment testing NR predicates in Czech consisted of two parts:

a) an acceptability judgment task,

b) an inference task.

\subsubsection{Acceptability Task: Materials}

The acceptability task tested how Czech native speakers accept so-called strict negative polarity items, or NPIs (Zwarts 1998). Strict NPIs are licensed in the subset of environments that license weak NPIs (on the latter, see, e.g., Ladusaw 1979). What is important for us is that it has been demonstrated that strict NPIs can be licensed by clausemate negation or by negated NR predicates, and consequently, they have often been used as tests for NR-hood (see, e.g., Gajewski, 2003). We will consider two types of strict NPIs:

a) ani jeden 'even one' $+\mathrm{N}$ type (like ani jedna ovce 'even one sheep'),

b) $a \check{z} d o$ 'until' + time expression

The acceptability of strict NPIs was judged on a Likert scale from 1 (absolutně nepríiatelná věta, 'sentence completely unacceptable') to 5 (věta je naprosto v pořádku, 'sentence fully acceptable').

We tested the acceptability of strict NPIs in five conditions:

(A) in positive sentences,

(B) in simple negative sentences,

(C) in clauses embedded under negated NR predicates of intention (e.g., want) and judgment/obligation (e.g., advise),

(D) in clauses embedded under negated NR predicates of opinion (e.g., believe),

(E) in clauses embedded under negated non-NR predicates (prototypically verbs of communication and causation - say, make, ...)

We split NR predicates into two conditions, $\mathrm{C}$ and $\mathrm{D}$, to see whether or not different semantic classes of NR predicates behave differently. This is of interest since B\&G tested NR across Slavic languages only on a representative of the opinion class, and it is 
conceivable that their conclusion were correct for that class, while group C does show properties of NR in Czech.

There were 40 items in the acceptability task. Five lists were constructed out of the items and conditions in such a way that each item appeared only once in any list and the five conditions were 'cycled' through the lists (repeated Latin-square design). Half of the items were tested with the strict NPI ani jeden, while the other half used the strict NPI $a z ̌ d o$. All of the items in the acceptability task were tested in all five conditions (A) - (E) from above. One example of an item with strict the NPI ani jeden is presented in (6) (verbs and strict NPIs are boldfaced in the example, but they were not marked in the experiment).

(6) a) Ztratila se ani jedna ovce.

lost SE even one sheep

'A single sheep is missing.'

b) Neztratila se ani jedna ovce.

neg-lost SE even one sheep

'Not a single sheep is missing.'

c) Novýbača v Tatrách nechce, aby se ztratila ani jedna ovce. new shepherd in Tatras neg-wants C-SUBJ SE lost even one sheep.

'The new shepherd in the Tatra mountains does not want a single sheep to be missing.'

d) Novýbača v Tatrách si nemyslí, že se ztratila ani jedna ovce. new shepherd in Tatras SI neg-think C-IND SE lost even one sheep 'The new shepherd in the Tatra mountains does not think that a single sheep is missing.'

e) Novýbača v Tatrách neříká, že-IND se ztratila ani jedna ovce. new shepherd in Tatras neg-say C SE lost even one sheep 'The new shepherd in the Tatra mountains does not say that a single sheep is missing.'

Since we deal with strict NPIs, we expect that negative sentences, like (6b), are more acceptable than positive sentences, like (6a). However, the most interesting case for us is the contrast between (6c) and (6d), on the one hand, and (6e), on the other hand. If Czech has NR predicates, we expect that the examples (6c) and (6d), in which strict NPIs are licensed, are more acceptable than (6e), in which the licensing of strict NPIs should not take place.

Careful readers might have noticed that embedded clauses in Conditions $\mathrm{C}$ and $\mathrm{D}$ in the example above differ in their mood: condition $\mathrm{C}$ uses subjunctive (glossed as SUBJ and realised on the complementiser), while Condition D and Condition E use indicative (glossed as IND on the complementiser). In the experiment, not every item had this distribution of mood. The items were constructed in such a way that (i) subjunctive mood was always used in Condition $\mathrm{C}$ because NR predicates of that group disallow any other mood, and (ii) 10 items in Condition D had an indicative mood, while the 
remaining 30 items used subjunctive. Furthermore, Condition E (non-NR predicates) had 15 items in the subjunctive mood and the remaining 25 items in the indicative mood. This arbitrary division of subjunctive and indicative was caused because we did not consider mood a relevant factor when designing the experiment. We will return to this issue in section 3.3.

The verbs we used in testing the (C) environment were intention/judgment/obligation verbs like the following: chtit 'want', hodlat, dopustit 'allow', mit v úmyslu 'have an intention', prát si 'wish', vyžadovat 'require, potřebovat 'need', usilovat 'strive', radit 'advise', doporučovat 'recommend', and navrhovat 'propose'. Examples of verbs from the (D) environment are opinion verbs like: myslet 'think', věrit 'believe', predpokládat 'suppose', představovat 'imagine', očekávat 'expect', uvažovat o 'speculate', domnivat se 'assume', soudit 'judge', and spoléhat se 'count on'. Lastly, in the (E) environment, we used non-NR predicates such as řikat 'say', slyšet 'hear', tvrdit 'assert', rozhlašovat 'rumour', naznačit 'indicate', prozradit 'reveal', sdělit 'tell', zavolat 'call', napsat 'write', způsobit 'cause', vyrozumèt 'inform', nutit 'force', čist 'read', and chápat 'understand'.

There were also 30 fillers in the acceptability task.

All of the stimuli were presented to each participant in a random order.

\subsubsection{Inference Task: Materials}

In the inference task, which always followed the acceptability task, we tested whether or not Czech native speakers found three entailments valid. The entailments are usually taken as another test for NR-hood (see Horn 1989 a.o.). The first condition tested the validity of NR itself ( $\neg \mathrm{NR}[\mathrm{P}] \sim \mathrm{NR}[\neg \mathrm{P}]$ ) illustrated in (7). Participants were asked whether or not (7b) follows from (7a). Note that the sentence is similar to the one used in the acceptability task, but there is no strict NPI used here. The second condition tested whether or not participants accept cyclic neg-raising $\left(\neg \mathrm{NR}_{1}\left[\mathrm{NR}_{2}[\mathrm{P}]\right] \sim\right.$ $\left.\mathrm{NR}_{1}\left[\mathrm{NR}_{2}[\neg \mathrm{P}]\right]\right)$. For example, they were asked whether or not (8b) follow from (8a). The final condition targeted the existential wide scope inference $\left(\neg \forall x \mathrm{NR}_{1}\left[\mathrm{NR}_{2}[\mathrm{P}]\right] \sim\right.$ $\left.\exists x \mathrm{NR}_{1}\left[\mathrm{NR}_{2}[\neg \mathrm{P}]\right]\right)$, i.e., whether or not (9b) follows from (9a).

(7 a) Novýbača v Tatrách nechce, aby se ztratila jediná ovce. new shepherd in Tatras neg-wants C-SUBJ SE lost single sheep 'The new shepherd in the Tatra mountains does not want a single sheep to be missing.'

b) Nový bača $v$ Tatrách chce, aby se neztratila jediná ovce. new shepherd in Tatras wants C-SUBJ SE neg-lost single sheep 'The new shepherd in the Tatra mountains wants no sheep to be missing.'

(8) a) Myslivci nevěř́, $\quad \check{z}$ e nový bača v Tatrách chce, abyse ztratila jediná ovce. hunters not-believe that new shepherd in Tatras wants C-SUBJ SE lost single sheep 'The hunters do not believe that the new shepherd in the Tatra mountains wants a single sheep to be missing.' 
b) Myslivci věrí, že novýbača v Tatrách chce, aby se neztratila jediná ovce. hunters believe that new shepherd in Tatras wants C-SUBJ SE neg-lost single sheep 'The hunters believe that the new shepherd in the Tatra mountains wants no sheep to be missing.'

(9) a) Ne všichni myslivci věř́, že novýbača v Tatrách chce, aby se ovce mèly dobře. not all hunters believe that new shepherd in Tatras wants C-SUBJ SE sheep had well 'Not all the hunters believe that the new shepherd in the Tatra mountains wants sheep to prosper.'

b) Někteři myslivci věří, že nový bača $v$ Tatrách chce, aby se ovce nemély dobře. some hunters believe that new shepherd in Tatras wants C-SUBJ SE sheep neg-be good Some hunters believe that the new shepherd in the Tatra mountains wants sheep not to prosper.'

Twenty items were used in the inference task. The items were split into three lists, so that each item appeared only once in each list and the conditions were 'cycled' through the items (in the same manner as in the acceptability task). Apart from the experimental items, the inference task also included 30 fillers. The experimental fillers were uncontroversial cases of either deductively valid inferences (like modus ponens: paraphrase of premises - If it rains, the streets are wet; It is raining; conclusion: The streets are wet) and cases of deductively non-valid inferences (logical fallacies). It is unlikely that the fillers had any impact on the inferences in the items and vice versa. The stimuli were presented in a random order.

\subsubsection{Procedure and Participants}

The experiment was prepared in Ibex and participants engaged with the experiment online. The experiment began with instructions, and these were followed by practice items and the acceptability task. Afterwards, the inference task was presented. Sixty native speakers of Czech, mostly students of linguistics in Brno, participated in the experiment, and they received course credit for their participation.

\subsection{Results of Acceptability Task}

The fillers in the acceptability task were uncontroversially grammatical or ungrammatical according to our intuitions, and we used them to check that participants understood the task. More concretely, we checked whether or not the average of each participant's responses to ungrammatical fillers was lower than the average of his or her responses to grammatical fillers. Indeed, every participant passed this test (there was at least a one point difference between the two averages). We kept all the participants for the subsequent analysis.

Responses in the acceptability task were modeled by mixed-effects ordered probit regression in the $\mathrm{R}$ package ORDINAL. ${ }^{2}$ The model had one predictor, Condition

2 The advantage of using ordered probit regressions as compared to the more familiar linear regression models is that the former only assumes that responses 1-5 are ordered, but does not 
(condition C, i.e., want type of neg-raisers, was the reference level). The model also included subject and item slope+intercept random effects. The statistical outcome was the following: ${ }^{3}$

a) simple negated sentences (Condition B) with strict NPIs were judged as better than NR predicates from the reference level $(\beta=3.2, z=7.3, p<.001)$,

b) simple positive sentences (Condition A) with strict NPIs were judged as worse than any NRs $(\beta=-1.5, z=-9.2, p<.001)$,

c) sentences with negated non-NR predicates (condition E) were worse than NR predicates $(\beta=-0.8, z=-5.6, p<.001)$

d) there was no significant difference between two types of NR predicates (Condition $\mathrm{C}$ and Condition D) $(\mathrm{p}>.1)$

The boxplots of the acceptability ratings depending on the five conditions are charted in Figure 1 and we think this graphical summary visually matches what has been found using inferential statistics. We conclude that the statistical analysis is compatible with the following hypotheses about Czech:

a) ani jeden 'even one' and $a \check{z} d o$ 'until' are strict NPIs (if they were weak NPIs, they would be grammatical in Condition E, negated non-NR predicates; if they were not polarity items, we would expect that they were acceptable in Condition A, positive sentences; both predictions are incompatible with our findings),

b) Czech has a class of NR verbs - NR verbs of intention, obligation, and opinion are able (with some interesting variation, discussed further) to license strict NPIs in their embedded clauses, unlike Czech non-NR predicates, hence the difference between Condition $\mathrm{C}$ and $\mathrm{D}$, on the one hand, and Condition $\mathrm{E}$, on the other hand. At the same time, there is a difference between NR predicates and clausemate negation in that strict NPIs are less acceptable in the former environment (cf. the difference between Condition $\mathrm{C}$ and $\mathrm{D}$, on the one hand, and Condition $\mathrm{B}$, on the other hand).

presuppose that the points in the scale are evenly spaced. Rather, the distance between any two points is modeled from data. This is good, since it is possible that participants do not treat Likert scales as linear, e.g., the difference between 1 and 2 may not be the same as the difference between 2 and 3.

3 When interpreting the outcome, it should help to know that thresholds between responses had the following estimates: $1|2: \beta=-1.1 ; 2| 3: \beta=-0.06 ; 3|4: \beta=0.7 ; 4| 5: \beta=1.6$. 


\section{Acceptability}
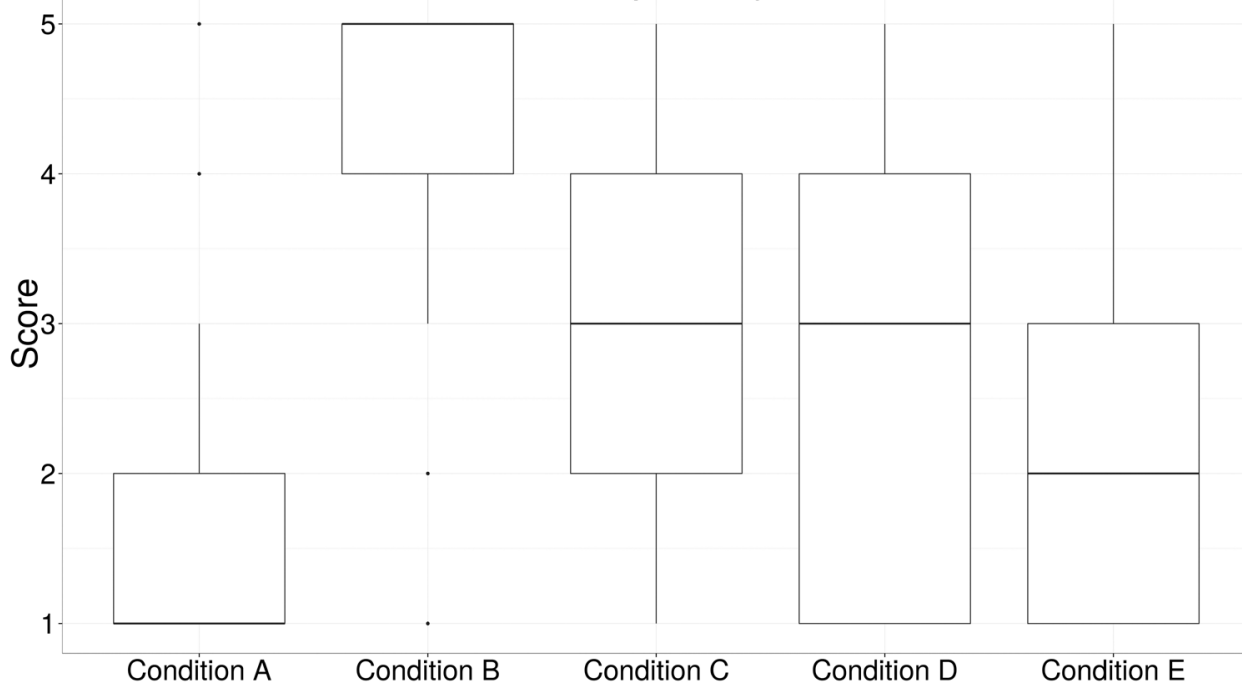

Figure 1: Results of the Acceptability Task

Two outstanding issues were investigated post-hoc. First, as noted above, we used two types of strict NPIs in the experiment. We wanted to see to which extent the two NPIs differ in acceptability. Secondly, two moods were used in NR predicates (subjunctive and indicative). Any differences between them in licensing strict NPIs were investigated. Importantly, the experiment was not designed to address either of the issues, so these results must be taken only as preliminary.

To study the first issue, we added a new factor to the model, NPI-type (with two factors, ani jeden 'even one' and $a z ̌$ do 'until' the former was the reference level) and its interaction with Condition (as before, Condition $\mathrm{C}$ was the reference level). The model had the same random-effect structure as the previous one. What we see is that in Condition $\mathrm{C}$, 'until' is more acceptable than 'even one' $(\beta=0.4, \mathrm{z}=2.4, \mathrm{p}<.05)$. As before, positive sentences and non-NR predicates are judged as worse $(\beta=-1.7$, $\mathrm{z}=-8.3, \mathrm{p}<.001$ and $\beta=-1.1, \mathrm{z}=-5.7, \mathrm{p}<.001$, respectively), and negative sentences as better $(\beta=4.7, z=10.4, p<.001)$. Condition $D$ was judged as slightly worse with 'even one' $(\beta=-0.4, z=2.5, p<.05)$. Importantly, NPI type interacted with Conditions: 'until' $\times$ Condition $\mathrm{D}$ and 'until' $\times$ Condition $\mathrm{E}$ led to higher acceptance $(\beta=0.6$, $\mathrm{z}=2.6, \mathrm{p}<.01$ and $\beta=0.6, \mathrm{z}=2.3, \mathrm{p}<.05$, respectively), while 'until' $\times$ Condition $\mathrm{B}$ (simple negative sentences) was less acceptable $(\beta=-3.2, \mathrm{z}=-6.4, \mathrm{p}<.001)$. The findings indicate that 'even one' is a better representative of strict NPIs than 'until' is. This is because 'even one' is fully acceptable with clausemate negation and it is somewhat degraded with negated NR predicates and even more so with negated non-NR 
predicates, which is a behaviour one would expect from strict NPIs (disregarding the somewhat degraded status with negated NR predicates, which will be discussed later). The situation is more complex for 'until'. As was the case for 'even one', the best environment for 'until' is clausemate negation, Condition B. However, compared to 'even one', 'until' is significantly less acceptable there, which is surprising if it was simply a plain, strict NPI. Even more interestingly, 'until' is more acceptable with negated NR and non-NR predicates (Conditions C, D and E) than 'even one' is. To take a step back, it seems that 'until' lacks an environment that would fully license it, unlike 'even one', at least as far as our experiment is concerned. This casts doubts on its status as a strict NPI and on using it as a testbed for NR-hood of predicates. Importantly for us, even when we restrict our attention only to 'even one'-NPIs, we still see that NR predicates (Conditions $\mathrm{C}$ and $\mathrm{D}$ ) are better licensors than non-NR predicates or positive sentences.

The second post-hoc issue concerned the subjunctive/indicative difference. To study this factor, we analysed only Conditions that used both moods (Condition D, NR predicates of opinion, and Condition E, non-NR predicates). Analysing the data in a mixed-effects ordered probit model with two fixed effects, Condition and Mood, we found that the indicative mood degraded acceptability $(\beta=-1.0, z=-4.7, p<.001)$, and so did non-NR predicates $(\beta=-0.8, z=-5.4, p<.001)$. The interaction of the two factors was not significant $(p>.1)$. To sum up, we see that mood plays a role in licensing strict-NPIs and unfortunately, this factor was not fully considered when we designed the experiment. At the same time, mood clearly cannot be the sole factor at play, since even after we added it to the model, the difference between NR and non-NR predicates remained a highly significant predictor of the acceptability of strict NPIs.

\subsection{Results of Inference Task}

The inference task was analysed in a mixed-effects logistic regression, where $1=$ inference follows and $0=$ inference does not follow, using R package LME4. Recall that the inference task consisted of three conditions:

Condition I: $\neg \mathrm{NR}[\mathrm{P}] \leadsto \mathrm{NR}[\neg \mathrm{P}]$

Condition II: $\neg \mathrm{NR}_{1}\left[\mathrm{NR}_{2}[\mathrm{P}]\right] \sim \mathrm{NR}_{1}\left[\mathrm{NR}_{2}[\neg \mathrm{P}]\right]$

Condition III: $\neg \forall x \mathrm{NR}_{1}\left[\mathrm{NR}_{2}[\mathrm{P}]\right] \sim \exists x \mathrm{NR}_{1}\left[\mathrm{NR}_{2}[\neg \mathrm{P}]\right]$

The model had one fixed factor, namely, Condition. The model also included intercept-only subject and item random effects (more complex models did not converge in LME4). In Condition I (the NR inference), the answer 1 (inference follows) was used in $65 \%$ of all cases, which was significantly higher than a chance (prob $=$ $0.5)(\beta=0.9, z=3.3, p=.001),{ }^{4}$ so for Condition I, we can safely say that NR reasoning was preferred.

For Condition II (cyclic NR) and Condition III (existential wide scope), response 1 (inference follows) was used in $49 \%$ and $48 \%$ of all cases respectively, which was not statistically different from chance $(\mathrm{prob}=0.5)(\mathrm{p}>0.1)$. These mixed results are

4 These values are based on a mixed-effect logistic regression with one factor, Condition, and subject and item intercept-only random effects. 
unexpected in all of the previous theoretical accounts of NR, whether they are based on presuppositions or implicatures. We suspect that two factors play a role here:

a) Conditions II and III are more complex than acceptability task and Condition I. This was particularly clear from response times - Conditions II and III took subjects 2-3 times longer than Condition I. It is reasonable to deduce that subjects became lost in complex sentences.

b) Conditions II and III always used the indicative mood in the first embedded clause. This will likely impede the NR-type inference, given that the indicative mood also blocks the licensing of strict NPIs by NR predicates (see Section 2.2).

\section{ANALYSIS}

We will now consider a framework that can explain all the main findings of our experiment. In particular, there are two asymmetries that our theory of NR will have to address:

a) NR predicates of intention, obligation, and opinion are better licensors of strict NPIs than non-NR predicates.

b) NR predicates are nevertheless worse strict-NPI licensors than clausemate negation.

We will consider a scalar approach to NR to capture both findings.

\subsection{The Scalar Approach to NR}

The scalar approach to NR was developed by Romoli (2012, 2013). In Romoli's approach, NR predicates are equipped with the set of alternatives that consists of the NR predicate itself, as well as the version in which the NR predicate is substituted by a predicate with excluded middle inference. An example is given in (10) for the NR predicate want and in (11) for think. The member in the set written as the first has the NR predicate itself, while the second member is the predicate with the excluded middle inference. The second member can be paraphrased as being opinionated in the case of think, or having a desire in the case of want. Note that the (10a) and (11a) versions are just informal descriptions of (10b) and (11b).

(10) a) $\operatorname{Alt}(\operatorname{want}(\mathrm{p})(\mathrm{x}))=\{\operatorname{want}(\mathrm{p})(\mathrm{x})$, have a desire as to whether( $\mathrm{p})(\mathrm{x})\}$

b) $\operatorname{Alt}(\operatorname{want}(\mathrm{p})(\mathrm{x}))=\left\{\square_{x}[p],\left[\square_{x}[p] \vee \square_{x}[\neg p]\right]\right\}$

(11) a) $\operatorname{Alt}(\operatorname{think}(\mathrm{p})(\mathrm{x}))=\{\operatorname{think}(\mathrm{p})(\mathrm{x})$, have an opinion as to whether $(\mathrm{p})(\mathrm{x})\}$

b) $\operatorname{Alt}(\operatorname{think}(\mathrm{p})(\mathrm{x}))=\left\{\square_{x}[p],\left[\square_{x}[p] \vee \square_{x}[\neg p]\right]\right\}$

As an example, consider the computation of the meaning of the sentence Susan wants to sleep. We will write the interpretation as in (12), in which $\square$ is the translation of the modal verb want (all the worlds compatible with Susan's wishes). $[\operatorname{sleep}($ susan $)]$ 
Crucially, this interpretation can be further strengthened. Romoli (2013), following Chierchia (2004), assumes that propositions are strengthened by an exhaustivity operator, EXH, similar in its meaning to only. EXH is lexically specified as affirming the proposition to which it attaches and negating excludable alternatives. Excludable alternatives are alternatives that can be negated without contradicting the basic meaning, see (13).

(13) a) $\operatorname{EXH}(\operatorname{Alt}(p))(p)(w)=p(w) \wedge \forall q \in \operatorname{Excl}(p, \operatorname{Alt}(p))[\neg q(w)]$

b) $\operatorname{Excl}(p, \operatorname{Alt}(p))=\{q \in \operatorname{Alt}(p): \lambda w[\neg q(w)] \cap p \neq \varnothing\}$

Coming back to our example, we can indicate the basic meaning and the meaning of negated alternatives as in (14). What is worth noting is that neither negated alternative is excludable. Both members of the set contradict the basic meaning. This should be obvious for the first member of the set. The second member can be rewritten as $\neg \square_{\text {susan }}[$ sleep(susan) $] \wedge \square_{\text {susan }}[\neg$ sleep(susan)], which also clearly contradicts the basic meaning. Because of that, alternatives do not play any role in this case and consequently, (14) results as the final meaning of the sentence.

(14) Basic: $\square_{\text {susan }}[$ sleep(susan) $]$

Negated alternatives:

$\left\{\neg \square_{\text {susan }}[\operatorname{sleep}(\right.$ susan $)], \neg\left[\square_{\text {susan }}[\operatorname{sleep}(\right.$ susan $)] \vee \square_{\text {susan }}[\neg$ sleep $($ susan $\left.\left.)]\right]\right\}$

The situation changes when we consider the sentence Susan does not want to sleep. The negated alternatives are as shown in (15b), where $p$ is an abbreviation of sleep(susan). Now, the second alternative (the disjunction of two propositions) is excludable, since it does not contradict the basic meaning. In fact, it strengthens it, as shown in (15b). The resulting interpretation is that Susan wants not to sleep, which is the neg-raising inference.

(15) a) Basic meaning: $\neg \square_{\text {susan }}[$ sleep(susan)]

a) Negated alternatives $=\left\{\neg \neg \square_{\text {susan }}[p], \neg \neg\left[\square_{\text {susan }}[p] \vee \square_{\text {susan }}[\neg p]\right]\right\}$ $=\left\{\square_{\text {susan }}[p],\left[\square_{\text {susan }}[p] \vee \square_{\text {susan }}[\neg p]\right]\right\}$

b) $\|E X H\|\left(\neg\right.$ want $\left._{s}[p]\right)=\neg \square_{\text {susan }}[p] \wedge\left[\square_{\text {susan }}[p] \vee \square_{\text {susan }}[\neg p]\right] \vDash$ want $_{s}[\neg p]$

The consequence of exhaustification of NR propositions is that negation is interpreted as having low scope. To put it more abstractly, $\neg N R(p)$ plus the alternative $N R(p) \vee N R(\neg p)$ entails $N R(\neg p)$.

Why should this entailment matter for strict NPIs, however? An answer to this question depends on what we believe the exact mechanism for licensing strict NPIs to be. Currently, three standard approaches are usually considered (see Gajewski 2005, 2011 for summary and details). Here, we will use that of Zwarts (1998): strict NPIs are licensed by anti-additive functions. Anti-additive functions are defined in (16). 
(16) A downward-entailing function $f$ is anti-additive iff for any $a$ and $b$ in the domain of $f$, $f(a)$ and $f(b) \leftrightarrow f(a$ or $b)$

Consider how (16) works for negation. (17b) follows from (17a) and vice versa, hence, we can conclude that negation is anti-additive and can license strict NPIs, which is correct. The same conclusion is shown more abstractly using propositional logic in $(17 \mathrm{c})$ and $(17 \mathrm{~d})$. That (17c) and (17d) are equivalent is a straightforward consequence of de Morgan's law.

(17) a) It didn't rain and it didn't snow.

b) It didn't rain or snow.

c) $\neg p \wedge \neg q$

d) $\neg[p \vee q]$

Crucially, the same conclusion holds for NR predicates. More concretely, (18b) follows from (18a) and vice versa, or, using modal logic, (18d) follows from (18c) and vice versa. To see the latter, notice that (18c) says that in no worlds does $p$ hold and in no worlds does $q$ hold. Then, however, it follows that that there are no worlds in which $p \vee q$ holds. Similarly, if there are no worlds in which $p \vee q$ holds then it must be that in no worlds does $p$ hold and in no worlds does $q$ hold.

(18) a) Susan does not want to sleep and she does not want to dance.

b) Susan does not want to sleep or dance.

c) $\square \neg p \wedge \square \neg q$

d) $\square \neg(p \vee q)$

For the equivalence of (18c) to (18d), we made use of the NR-hood of the predicate want. Had we not done so, anti-additivity would not be maintained. In other words, (19b) does not follow from (19a). To see that, consider the following. (19a) is true if there is a world in which $p$ is not true and a world in which $q$ is not true. However, (19b) requires that there is a world in which neither $p$ nor $q$ is true. That does not follow. In particular, if $p$ is false only in the world $w_{1}$ and $q$ is false only in the world $w_{2}$, then (19a) is true and yet, (19b) is false.

(19) a) $\neg \square p \wedge \neg \square q$
b) $\neg \square(p \vee q)$

If this interpretation of NR and strict NPIs are correct, it follows that the NR inference (and with it, strict NPI licensing) should depend on various factors. First of all, the alternatives must reach the EXH operator. Secondly, the alternatives must be relevant (see Romoli 2013, Sect. 7). Consider (20). The alternatives are relevant if (20) is an answer to a question under discussion (QUD) such as What does the new shepherd want 
his sheep to do? However, the exhaustification might not be an option. We will discuss this possibility in the next section.

(20) The new shepherd in the Tatra mountains doesn't want even one sheep to be missing.

The last question we must address is why we see no NR-like inferences with nonNR predicates. Romoli's answer, which we again follow here, is that alternatives triggering NR are absent for non-NR predicates. For example, the non-NR predicate be certain has universal and existential quantification over possible worlds as its alternatives. This is shown in (21). Negating the existential alternative of (21) yields the inference demonstrated in (21a). The full meaning is represented in (21b). Applied to the data in our experiment: we observed that negated non-NR predicates are unable to license strict NPIs in embedded clauses. This follows since non-NR predicates do not trigger the low-scope interpretation of negation, even when exhaustified, and the antiadditive inference is not valid.

(21) John isn't certain that Mary will arrive.

a) $\sim$ It's possible for John that Mary will arrive.

b) $\neg \square_{j}[p] \wedge \vartheta_{j}[p]$

\subsection{NR Suspension - NR vs. Simple Negated Sentences}

We now turn to the question as to why strict NPIs are fully licensed by clausemate negation, while negated NR predicates are worse licensors. Gajewski (2007) observes that, in English, NR inferences can be suspended if the auxiliary in the main clause is stressed. John DOESN'T think that Fred left can be used to express that John is not sure about Fred's whereabouts. We believe that similar suspension can take place in Slavic.

One way to capture the suspension of inferences is to say that only relevant alternatives can yield inferences, and what counts as relevant can be modeled using questions under discussion (QUD). In this perspective, every sentence can be seen as an answer to its (implicit or explicit) QUD. QUDs, in turn, are questions that partition the common ground. Relevance is then defined as follows (following Romoli 2013):

(22) Relevance: A proposition $\mathrm{p}$ is relevant to a question $\mathrm{Q}$ iff $\mathrm{p}$ is (contextually equivalent with) the union of some subset of $\mathrm{Q}$.

An example of a QUD is found in (23). This question creates a partition like (20a): affirmative propositonal attitude, negative propositional attitude, and ignorance. In such a context, the alternative triggering low-scope negation is relevant because it is equivalent with $c_{3}$.

(23) What does the new shepherd want his sheep to do?
a) $Q=\left\{c_{1}=\right.$ want $_{s}[p], c_{2}=$ want $_{s}[\neg p], c_{3}=\neg\left(\right.$ want $_{s}[p] \vee$ want $\left.\left._{s}[\neg p]\right)\right\}$ 
Given that QUDs affect inferences, they can modulate licensing of strict NPIs. Consider (24), in which, according to our intuitions, the stress on the verb blocks the strict NPI in the embedded clause (a proper experimental study that would take intonation into account would be needed here, of course). The focus is the affirmative/negative polarity of the clause. (There is another interpretation, in which the verb itself is the focus, but that is irrelevant for now.) Theoretically, we model this through the QUD in (25), which leads to the partition in (25a). In this case, the alternative triggering low-scope negation, namely, $\neg\left(\right.$ think $\left.[p] \vee \operatorname{think}_{s}[\neg p]\right)$, is not relevant because it is not equivalent to any member in the partition. Consequently, the crucial inference licensing strict NPIs in the embedded clause is not calculated. ${ }^{5}$

(24) Novýbača si NEMYSLÍ, že se ztratila *ani jedna ovce. new shepherd SE DOESN'T-think that SE disappeared even-one one sheep

(25) Does the new shepherd think that one sheep dissapeared?

a) $Q=\left\{c_{1}=\operatorname{think}_{s}[p], c_{2}=\neg \operatorname{think}_{s}[p]\right\}$

This argumentation explains why simple negated sentences (Condition B) are always better as strict NPI licensors: their licensing ability is not dependent on exhaustification and hence is not sensitive to context manipulation. One might wonder, however, why Czech and English differ. In English, licensing strict NPIs by NR predicates has never been questioned, as far as we know. In contrast to this, Slavic NRs have a less clear status, as seen in the disagreement in the literature (Bošković \& Gajewski 2009 vs. Dočekal 2014), and as also visible in the lower scores of NR predicates in our acceptability study.

One option is that different morphosyntax of the two markers is to blame. English negation triggers $d o$-support and thus, QUD targeting polarity can be straightforwardly marked by stressing the negation itself (plus its host, the semantically vacuous $d o$ ). This is not possible in Czech, in which (the clausal) negation is a bound morpheme, must be attached to the verb, and cannot be independently stressed. ${ }^{6}$ Since it is not possible to unambiguously mark the QUD, targeting polarity, Czech speakers are likely to consider this interpretation without any specific signal. Consequently, Czech speakers might suspend the crucial inference more freely.

\subsection{Subjunctive vs. Indicative}

We noted in our discussion of the experiment that two factors affect the licensing of strict NPIs in embedded clauses: one was the type of the matrix predicate (NR or

5 Romoli (2013) uses a different approach for licensing strict NPIs, following Gajewski (2011). Somewhat simplified, the theory states that strict NPIs are licensed only if the meanings strengthened by the application of EXH are downward-entailing. This approach would predict that cases like (24) allow strict NPIs.

6 This is also the reason that the example (21), with the stress on verb, can be understood as focusing the polarity of the sentence or the verb itself. 
not-NR), and the analysis of that effect was provided in the previous section. The second factor is the mood in the embedded clause (subjunctive vs. indicative). We assume that the indicative inhibition of NR inference is the second main factor behind the limited NR-hood of Slavic languages and we believe that it is not coincidental that all of B\&G's examples against NR in Slavic are based on indicative embedded clauses.

The indicative/subjunctive difference is orthogonal to our main interests and would probably merit a paper in its own right, so we will only shortly indicate what a possible approach could look like. One option is that strict NPIs are better licensed by the subjunctive than by the indicative mood, because the subjunctive is known to be more transparent for cross-clausal phenomena (see Progovac 1993 a.o.). Translating this into semantics, it was observed (see Villalta 2008) that only the subjunctive mood transfers alternatives from the embedded clause to the matrix predicate, whereas the indicative mood blocks them. Since the inference licensing of strict NPIs requires the projection of alternatives from the embedded clause, it would follow that the subjunctive mood is compatible with strict NPIs, while the indicative mood is not.

\section{CONCLUSION}

In this article, we discussed an experiment targeting neg-raising in Czech. Contrary to B\&G's (2009) claims, we argued that NR exists in Czech (a Slavic language without articles). We demonstrated that strict NPIs are more acceptable under NR predicates than under non-NR predicates, which follows naturally if Czech has a class of NR predicates. It is not clear to us how B\&G (2009) could explain this contrast.

Somewhat surprisingly, we observed a contrast between clausemate negation and NR predicates with respect to strict NPI licensing. However, we explained these data while maintaning that NR-hood exists in Czech. In particular, we argued that the data follow under the scalar theory of NR (Romoli, 2012, 2013) and the anti-additive licensing condition for strict NPIs.

Several issues were discovered in our experiment and remain open. One is the observed effect of the mood on the licensing of strict NPIs. Another is the difference between 'even one' and 'until' and their interaction with licensing environments. Issues like these reveal that more than 50 years after Fillmore brought neg-raising to linguists' attention (Fillmore, 1963), neg-raising still does not have the last word.

\section{References}

ABUSCH, Dorit (2002) "Lexical Alternatives as a Source of Pragmatic Presuppositions." Semantics and Linguistic Theory (SALT) 12, 1-19 http://semanticsonline. org/pragmatics/protected/abusch.pdf.

BARTSCH, Renate (1973) “'Negative Transportation' gibt es nicht.” Linguistische Berichte 27, 1-77.

BOŠKOVIĆ, Željko/Jon GAJEWSKI (2009) "Semantic Correlates of the NP/DP Parameter." Proceedings of NELS 39, 121-134. 
CHIERCHIA, Gennaro (2004) "Scalar Implicatures, Polarity Phenomena, and the Syntax/Pragmatics Interface." In: A. Belletti (ed.), Structures and Beyond: The Cartography of Syntactic Structures. Oxford: Oxford University Press, 39-103.

CHIERCHIA, Gennaro (2013) Logic in Grammar: Polarity, Free Choice, and Intervention. Vol. 2. Oxford: Oxford University Press.

COLLINS, Chris, and Paul M. POSTAL (2014) Classical NEG Raising: An Essay on the Syntax of Negation. Cambridge, MA: MIT Press.

DOČEKAL, Mojmír (2014) "Intervention Effects: Negation, Universal Quantifiers, and Czech.” In: M. Ludmila/J. Veselovská (eds) Complex Visibles Out There. Olomouc: Palacký University, 369-387.

DOČEKAL, Mojmír (2015) Czech Negation from the Formal Perspective. Munich: Lincom.

FILLMORE, Charles J. (1963) "The Position of Embedding Transformations in a Grammar." Word 1, 208-231.

GAJEWSKI, Jon Robert (2005) Neg-Raising: Polarity and Presupposition. PhD Dissertation. Massachusetts Institute of Technology. http://gajewski.uconn.edu/papers/thesis.pdf.

GAJEWSKI, Jon Robert (2007) "Neg-Raising and Polarity." Linguistics and Philosophy 30/3, 289-328.

GAJEWSKI, Jon Robert (2011) "Licensing Strong NPIs." Natural Language Semantics 19, 109-148.

HINTIKKA, Jaakko (1962) Knowledge and Belief. Ithaca, NY: Cornell University Press.

HOMER, Vincent (2008) "Disruption of NPI Licensing: The Case of Presuppositions." Proceedings of SALT 18. 429-46.

HORN, Laurence R. (1989) A Natural History of Negation. Chicago: University Of Chicago Press.

LADUSAW, William A. (1979) Polarity Sensitivity as Inherent Scope Relations. PhD Dissertation. University of Texas, Austin.

LAKOFF, Robin (1969) "A Syntactic Argument for Negative Transportation." Proceedings of CLS 5, 149-157.

PROGOVAC, Ljiljana (1993) "Subjunctive: The (Mis)Behavior of Anaphora and Negative Polarity." The Linguistic Review 10, 37-59.

ROMOLI, Jacopo (2012) Soft but Strong. Neg-Raising, Soft Triggers, and Exhaustification. PhD Dissertation. Harvard University.

ROMOLI, Jacopo (2013) "A Scalar Implicature-Based Approach to Neg-Raising." Linguistics and Philosophy 36/4, 291-353.

VILLALTA, Elisabeth (2008) "Mood and Gradability: An Investigation of the Subjunctive Mood in Spanish." Linguistics and Philosophy 31/4, 467-522.

ZWARTS, Frans (1998) “Three Types of Polarity.” In: F. Hamm/E. W. Hinrichs (eds), Plurality and Quantification. Dordrecht: Kluwer, 177-238. 


\section{Summary \\ EXPERIMENTAL EVIDENCE FOR NEG-RAISING IN SLAVIC}

Most research studying neg-raising focuses on English. Two notable exceptions are Bošković \& Gajewski (2009) and Dočekal (2014) who discuss neg-raising in Slavic. In contrast to Bošković \& Gajewski (2009), Dočekal (2014) argues that predicates of intention and obligation pass standard tests for neg-raisers in Czech. This article discusses new experimental data that provide additional evidence for the existence of negraising in Slavic languages, in particular, in Czech. The experiment that is conducted to test neg-raising predicates consists of an acceptability judgment task and an inference task. Sixty native speakers of Czech participated in the study. The results of the experiment are interpreted in Romoli's scalar theory of neg-raising (Romoli 2012, 2013). We claim that neg-raising exists in Czech, and argue that strict negative polarity items are more acceptable under neg-raising predicates than under non-neg-raising predicates.

Keywords: formal semantics, implicatures, neg-raising, Slavic, Czech

\section{Povzetek \\ EKSPERIMENTALNI DOKAZI ZA DVIGANJE NIKALNICE V SLOVANSKIH JEZIKIH}

Večina raziskav s področja dviganja nikalnice se osredinja na angleščino. Prispevka Boškovića in Gajewskega (2009) ter Dočekala (2014) sta izjema na tem področju, saj obravnavata dviganje nikalnice $\mathrm{v}$ slovanskih jezikih. V nasprotju z izsledki Boškovića in Gajewskega (2009) Dočekal (2014) trdi, da predikati, ki izražajo namen in obvezo, dovoljujejo dviganje nikalnice v češčini. Pričujoči članek obravnava izsledke eksperimentalne raziskave, ki dodatno dokazujejo obstoj dviganja nikalnice $\mathrm{v}$ slovanskih jezikih, natančneje v češčini. Eksperiment, $\mathrm{s}$ katerim smo opazovali predikate $\mathrm{z}$ dviganjem nikalnic, sestavljata naloga s sodbami o sprejemljivosti in naloga iz sklepanja. Sodelovalo je šestdeset domačih govorcev češčine. Rezultati raziskave so obravnavani $\mathrm{z}$ vidika skalarne teorije o dviganju nikalnic avtorja Jacopa Romolija (Romoli 2012, 2013). V članku trdimo, da dviganje nikalnici v češčini obstaja, in zagovarjamo trditev, da so strogi k nikalnosti usmerjeni izrazi bolj spremenljivi v predikatih $\mathrm{z}$ dviganjem nikalnice kot $\mathrm{v}$ predikatih brez dviganja nikalnice.

Ključne besede: formalna semantika, implikatura, dviganje nikalnice, slovanski jeziki, češčina 